\title{
Evaluation of the effectiveness of in vitro fungicides against the pathogen of rot of the core of apple fruit Alternaria alternata (Fries: Fries) Keissler \\ Yakuba G.V., Astapchuk I.L.
}

Federal State Budget Scientific Institution "North Caucasian Federal Scientific Center of Horticulture, Viticulture, Wine-making" Russia, Krasnodar

E-mail: galyayaku@gmail.com

Key message. We studied the sensitivity to fungicides in vitro of the rot pathogen of the core of apple fruit A. alternata. The Luna Tranquility, SC showed an effectiveness of $95 \%$, the fungicides Granuflo, WDG and Chorus, WDG -70 and $75 \%$, respectively.

Keywords: apple-tree, Alternaria alternata, fungicides, in vitro, efficiency

In the mycopathopathocenosis of an apple tree in Southern Russia, the fungus Alternaria alternata (Fries: Fries) Keissler infects flowers with the subsequent development of core rot in the fruit [1]. Since 2015, there has been an increase in the prevalence, severity of the disease and a decrease in the effectiveness of protective measures against mycosis in some areas [2]. Goal of research: to determine the effectiveness of fungicides of chemical origin against the pathogen of rot of the fruit core A. alternata in vitro. Sowing of the isolate of the fungus was performed on potato glucose agar (PGA) medium in triplicate. Calculation of the concentration of conidia and the amount of the drug per area of one Petri dish, as well as analysis of the effect on the suppression of culture growth (aerial mycelium) after 7 days at $25^{\circ} \mathrm{C}$, was carried out according to the generally accepted method [3]. The following preparations were used in the work: Chorus (cyprodinil, $750 \mathrm{~g} / \mathrm{kg}$ ), WDG $0.025 \%$ (concentration of fungicide); Luna Tranquility (fluopyram, $125 \mathrm{~g} / \mathrm{l}+$ pyrimethanil, $375 \mathrm{~g} / \mathrm{l}$ ), SC - 0.12\%; Granuflo (tiram, $800 \mathrm{~g} / \mathrm{kg}$ ), WDG - 0.30\%; Score (diphenoconazole, $250 \mathrm{~g} / \mathrm{l}$ ) served as the standard, EC - 0.035\%, control - distilled water. In specie A. alternata, a high sensitivity to the studied fungicides in vitro was revealed. On the 7 th day of the growth of pathogen colonies, the coating of the Petri dish with air mycelium in the variants of the tested preparations was from 5 to 30 $\%$, in the control $-100 \%$. The drug Luna Tranquility, SC showed high efficacy against micromycete - $95 \%$, fungicides Granuflo, WDG and Chorus, WDG - slightly less effective in suppressing the growth of $A$. alternata aerial mycelium: 70 and $75 \%$, respectively. Fungicide Score, EC inhibited the growth of the mycelium of the fungus by $100 \%$. Now therefore, initial in vitro fungicide screening showed that the fungicides studied have a rather high efficiency of suppressing the growth of the mycelium of the pathogen of alternative rot of the fruit core. However, our studies have found that drugs do not completely reduce the number of fungal colonies, therefore, work on the evaluation of drugs in vitro must be continued with the study of more signs.

\section{Оценка эффективности фунгицидов in vitro против возбудителя гнили сердцевины плодов яблони Alternaria alternata (Fries: Fries) Keissler}

\author{
Якуба Г.В., Астапчук И.Л.
}

ФГБНУ «Северо-Кавказский федеральный научный центр садоводства, виноградарства, виноделия»

\begin{abstract}
Аннотация. Была изучена чувствительность к фунгищидам іп vitro возбудителя гнили сердцевинь плодов яблони Alternaria alternata. Препарат Луна Транквилити, КС показал эффективность 95 \%, фунгициды Грануфло, ВДГ и Хорус, ВДГ-70 и 75 \% соответственно, при эффективности стандарта $100 \%$.

Ключевые слова: яблоня, Alternaria alternata, фунгициды, in vitro, эффективность

В микопатоценозе яблони на Юге России гриб Alternaria alternata (Fries: Fries) Keissler заражает цветки с последующим развитием у плодов гнили сердцевины [1]. С 2015 г. отмечено увеличение распространенности, вредоносности заболевания и снижение на отдельных участках эффективности защитных мероприятий против микоза [2]. Цель исследования: определить эффективность фунгицидов химического происхождения против возбудителя гнили сердцевины плодов A. alternata in vitro. Посев изолята гриба был произведен на среду КГА в трехкратной повторности. Расчет концентрации конидий и количества препарата на площадь одной чашки Петри, а также анализ влияния на подавление роста культуры (воздушного мицелия) спустя 7 суток при $25^{\circ} \mathrm{C}$ производили по общепринятой методике [3]. В работе были использованы следующие препараты: Хорус (750 г/кг ципродинила), ВДГ - 0,025\% (концентрация по препарату); Луна Транквилити (125 г/л флуопирама + 375 г/л пириметанила), КС - 0,12\%; Грануфло (800 г/кг тирама), ВДГ - 0,30\%; стандартом служил Скор (250 г/л дифеноконазола), КЭ - 0,035 \%, контролем дистиллированная вода. У вида A. alternata была выявлена высокая чувствительность к изученным фунгицидам in vitro. На 7- е сутки роста колоний патогена покрытие чашки Петри воздушным мицелием составляло в вариантах испытуемых препаратов от 5 до $30 \%$, в контроле - $100 \%$. Препарат Луна Транквилити, КС показал высокую эффективность против микромицета - $95 \%$, фунгициды Грануфло, ВДГ и Хорус, ВДГ - несколько меньшую эффективность в подавлении роста воздушного мицелия A. alternata: 70 и 75 \% соответственно. Фунгицид Скор, КЭ подавлял рост мицелия гриба на $100 \%$.

Таким образом, первичный скрининг фунгицидов in vitro показал, что изученные фунгициды имеют достаточно высокую эффективность подавления роста мицелия возбудителя альтернариозной гнили сердцевины плодов. Однако наши исследования выявили, что препараты полностью не сокращают количество колоний гриба, следовательно, работу по оценке препаратов in vitro необходимо продолжить с изучением большего количества признаков.
\end{abstract}

1. Якуба Г.В. Эволюция паразитических свойств Alternaria alternata (Fries: Fries) Keissler на яблоне в условиях Краснодарского края / Плодоводство и ягодоводство России. 2010. Т. 24. № 2. С. 380-386.

2. Якуба Г.В. Видовая структура комплекса микромицетов, возбудителей гнили сердцевины плодов яблони Краснодарского края / Г.В. Якуба, И.Л. Астапчук, А.И. Насонов // Плодоводство и виноградарство Юга России. 2019. № 60 (6). С. 148-162.

3. Методика определения биологической эффективности фунгицидов в отношении грибов рода Fusarium и их резистентности к химическим препаратам / В.В. Чекмарев и др.; Из-во обр. и науки РФ (и др.). - Тамбов: Принт-Сервис, 2015. -61с. 